\title{
Investigation of the ozone formation potential for ethanol using a smog chamber
}

\author{
JIA Long, XU YongFu* \& SHI YuZhen \\ State Key Laboratory of Atmospheric Boundary Layer Physics and Atmospheric Chemistry, Institute of Atmospheric Physics, Chinese Academy of \\ Sciences, Beijing 100029, China
}

Received April 13, 2012; accepted May 28, 2012; published online August 7, 2012

\begin{abstract}
The ozone formation reactivity of ethanol has been studied using chamber experiments and model simulations. The computer simulations are based on the MCM v3.1 mechanism with chamber-dependent auxiliary reactions. Results show that the MCM mechanism can well simulate $\mathrm{C}_{2} \mathrm{H}_{5} \mathrm{OH}-\mathrm{NO}_{x}$ chamber experiments in our experimental conditions, especially on ozone formation. $\mathrm{C}_{2} \mathrm{H}_{5} \mathrm{OH}-\mathrm{NO}_{x}$ irradiations are less sensitive to relative humidity than alkane species under our experimental conditions. In order to well simulate the experiments under high relative humidity conditions, inclusion of $\mathrm{N}_{2} \mathrm{O}_{5}+\mathrm{H}_{2} \mathrm{O}=2 \mathrm{HNO}_{3}$ in the MCM mechanism is necessary. Under $\mathrm{C}_{2} \mathrm{H}_{5} \mathrm{OH}$-limited conditions, the $\mathrm{C}_{2} \mathrm{H}_{5} \mathrm{OH} / \mathrm{NO}_{x}$ ratio shows a positive effect on $\mathrm{d}\left(\mathrm{O}_{3}-\mathrm{NO}\right) / \mathrm{dt}$ and $\mathrm{RO}_{2}+\mathrm{HO}_{2}$. High $\mathrm{C}_{2} \mathrm{H}_{5} \mathrm{OH} / \mathrm{NO}_{x}$ ratios enhance the production of organoperoxide radical and $\mathrm{HO}_{2}$ radical concentrations, which leads to a much quicker accumulation of ozone. By using ozone isopleths under typical scenarios conditions, the actual ozone formation ability of ethanol is predicted to be 2.3-3.5 part per billion (ppb) in normal cities, 3.5-146 ppb in cities where ethanol gas are widely used, and $0.2-3.2 \mathrm{ppb}$ in remote areas. And maximum ozone formation potential from ethanol is predicted to be 4.0-5.8 $\mathrm{ppb}$ in normal cities, $5.8-305 \mathrm{ppb}$ in cities using ethanol gas, and $0.2-3.8 \mathrm{ppb}$ in remote areas.
\end{abstract}

ethanol, ozone, photochemical smog, MCM, smog chamber

Citation: Jia L, Xu Y F, Shi Y Z. Investigation of the ozone formation potential for ethanol using a smog chamber. Chin Sci Bull, 2012, 57: 4472-4481, doi: $10.1007 / \mathrm{s} 11434-012-5375-9$

Ozone pollution produced by volatile organic compounds (VOCs) and nitrogen oxides $\left(\mathrm{NO}_{x}, x=1,2\right)$ irradiations is a serious environmental problem in large cities all over the world. There are many studies to investigate ozone formation potential of different types of VOC spices [1-6]. Ethanol $\left(\mathrm{C}_{2} \mathrm{H}_{5} \mathrm{OH}\right)$ is widely used as a solvent and a popular biofuel alternative to gasoline in the world. China has promoted ethanol-based fuels on a pilot basis in five cities in its central and northeastern regions since 2002 (http://english. people.com.cn/200206/17/eng20020617_98009.shtml). The annual output of ethanol fuels was 486 millions of U.S. liquid gallons in 2007 (http://www.ethanolrfa.org/page/-/objects/ pdf/outlook/RFA_Outlook_2008.pdf). With the increasing common use of ethanol, the ethanol concentrations in the atmosphere will probably increase.

*Corresponding author (email: xyf@mail.iap.ac.cn)
Atmospheric ethanol has been measured for more than 20 years. It has been found that urban mean concentrations of ethanol range from 0.7 to $12 \mathrm{ppb}$, whereas the cities where the ethanol gas is widely used exhibit the highest ethanol mean concentrations from 12.1 to $414 \mathrm{ppb}$ [7]. Both anthropogenic and natural sources make the contribution of ethanol concentrations. $4.8 \mathrm{ppb}$ of ethanol was found upwind a furniture factory and $461 \mathrm{ppb}$ downwind [8]. The role of natural sources is small in the urban areas. It has been found that the ethanol concentrations from natural sources spread from 0.04 to $1.2 \mathrm{ppb}$ in rural and remote areas. In forested areas the ethanol concentrations due to sources from trees and pastures are much higher [7].

There are still many arguments about ethanol's pollution problems, especially about its ozone pollution problem. Pereira et al. [9] used a mixture $22 \%-24 \%$ of anhydrous ethanol in gasoline and hydrated ethanol as potential precursors 
for ozone formation, and found that the ozone peak concentrations are in average $28 \%$ higher for alcohol than for the mixture. Jacobson [10] studied the effects of ethanol versus gasoline vehicles on cancer and mortality in the United States, and found that ethanol may make air even dirty and increase ozone-related mortality. Howard et al. [11] directly measured the ozone formation potential from dairy emissions using a mobile chamber, and found that the majority of the ozone formation could be mainly explained by ethanol in the emissions from the dairy cows, but the ozone formation potential is generally small. In addition, the maximum incremental reactivity (MIR) of $0.43 \mathrm{ppm} / \mathrm{ppmC}$ for ethanol reported by Carter [3] indicates that the ozone formation potential of ethanol may be important.

Nevertheless, the chamber experiments about the reactivity of ethanol are still limited. The object of this work is to study the role of ethanol in ozone formation in terms of chamber experiments. Several $\mathrm{C}_{2} \mathrm{H}_{5} \mathrm{OH}-\mathrm{NO}_{x}$-air irradiations were performed under different conditions. The results are used to study different factors impacting on the ozone formation from ethanol. The detailed chemical mechanism of ethanol from the Master Chemical Mechanism (MCM v3.1) is used to explain the decay process of ethanol. The experimental data are compared with the model simulation. Combination of experimental data and simulation results gives the reactivity of ethanol. The ozone formation potential of ethanol is further discussed.

\section{Experimental}

\subsection{Equipment}

A smog chamber was designed to investigate the photochemistry of volatile organic compounds. The whole facility has been used to study the reactions of ozone with ethylene [12], propylene [13], dimethyl sulfide [14] and isopentane [15]. The detail descriptions of the apparatus have been given in our previous works. Here only a brief summary is given. The enclosure that housed the Teflon bag (100-L) and Ultra-violet lamps were constructed using wood. The inner surface of the enclosure was coated with aluminum sheeting. Three thermometers with a precision of $0.2 \mathrm{~K}$ were placed in the chamber. Four blacklight lamps $(40 \times 4 \mathrm{~W}$, Model F40T8BL, with peak intensity at a wavelength of $350 \mathrm{~nm}$ ) were used to simulate the ground-level solar radiation in the experiments. During the reaction, the $\mathrm{O}_{3}, \mathrm{NO}_{x}$ and $\mathrm{CO}$ concentrations were monitored in real time using the Model $49 \mathrm{C}-\mathrm{O}_{3}$ Analyzer, the Model 42C-NO $\mathrm{N}_{x}$ Analyzer and Model 48C-CO Analyzer, respectively. The linearity of above equipments is $\pm 1 \%$ in the full detection range. The RH was measured by JinMin relative humidity analyzer with the accuracy of $\pm 2.5 \%$.

\subsection{Experimental reagents}

An ethanol gaseous mixture employed in the experiments was prepared from pure ethanol $\left(\mathrm{C}_{2} \mathrm{H}_{5} \mathrm{OH}, \mathrm{AR} \geqslant 99.7 \%\right.$, Beijing Chemical Factory) in a $2 \mathrm{~L}$ bottle and diluted by high-purity $\mathrm{N}_{2}$. The prepared gaseous ethanol mixture was injected into the reactor using a syringe. Ethanol concentrations in the reactor were calculated from the amount of organic compounds introduced into the reactor and the volume of background air used in the experiments. It was confirmed that the calculated concentrations of ethanol agreed to within better than $\pm 5 \%$ with the concentrations quantitatively detected by the gas chromatograph of GC112A (Shanghai Precision Scientific Instrument Co, Ltd). $\mathrm{CO}, \mathrm{NO}$ and $\mathrm{NO}_{2}$ in a purity of $99.9 \%$ were from the Beijing ZG Special Gases Science \& Technology Co., Ltd. Low concentration $\mathrm{NO}_{2}(9 \mathrm{ppm})$ was a gaseous mixture of high-purity $\mathrm{N}_{2}$ (Chinese National Research Center for CRM's).

\subsection{Experimental procedure and conditions}

In this study, two sets of experiments were conducted to investigate $\mathrm{O}_{3}$ formation of ethanol under different relative humidity conditions, including the $5 \%$ and $50 \%$ RH conditions. Before experiments, the reactor was washed using $\mathrm{N}_{2}$ (99.9992\%), until $\mathrm{O}_{3}$ and $\mathrm{NO}_{x}$ concentrations were under the detecting limit. For low RH condition experiments, after synthetic air was introduced into the reactor as background gas, the given quantity of ethanol and $\mathrm{NO}_{x}$ was sequentially introduced into the reactor. Then the reactor was vigorously shaken to make the reactants mixed thoroughly. For the experiments under the $53 \% \mathrm{RH}$ condition, a given quantity of the pure water was injected into the reactor directly with a syringe, and measured by JinMin RH analyzer when water was completely evaporated. After which the reactor was maintained in the dark for $1 \mathrm{~h}$ without any activities. Then the light was switched on for irradiation, and meantime a fan was turned on to keep the same temperature in the closure. During each experimental course, the temperature varied about $\pm 1 \mathrm{~K}$, and the reactants like $\mathrm{O}_{3}$ and $\mathrm{NO}_{2}$ were monitored on line. After each experiment the reactor was flushed using purified air for about $10 \mathrm{~h}$ with a $40 \mathrm{~W}$ blacklight lamp on. Relative light intensity in the chamber was measured by the $\mathrm{NO}_{2}$ photolysis rate constant, which was obtained to be $0.1572 \mathrm{~min}^{-1}$.

\section{Model simulations}

In order to compare the chamber experiments summarized in Table 1 with our current understanding of atmospheric chemical reactions, calculations were carried out using the Master Chemical Mechanism (MCM v3.1). Some chamber dependent auxiliary mechanisms were established using $\mathrm{O}_{3}$-air, $\mathrm{NO}_{x}$-air and $\mathrm{CO}-\mathrm{NO}_{x}$-air irradiation experiments, which include the wall effects of $\mathrm{O}_{3}$ and $\mathrm{NO}_{2}$, and the heterogeneous reaction between $\mathrm{H}_{2} \mathrm{O}$ and $\mathrm{NO}_{2}$. By fitting the experimental data, the reaction constant $(k)$ of the $\mathrm{O}_{3}$ wall 
Table 1 Initial experimental conditions for $\mathrm{C}_{2} \mathrm{H}_{5} \mathrm{OH}-\mathrm{NO}_{x}$-air irradiations

\begin{tabular}{|c|c|c|c|c|c|c|c|}
\hline Exp. No. & NO (ppb) & $\mathrm{NO}_{2}(\mathrm{ppb})$ & $\mathrm{NO}_{x}(\mathrm{ppb})$ & $\mathrm{C}_{2} \mathrm{H}_{5} \mathrm{OH}(\mathrm{ppm})$ & $\mathrm{RH}(\%)$ & $T(\mathrm{~K})$ & $\mathrm{C}_{2} \mathrm{H}_{5} \mathrm{OH} / \mathrm{NO}_{x}$ \\
\hline 1 & 204.0 & 50.0 & 254.0 & 4.2 & 5 & 293 & 16.5 \\
\hline 2 & 94.5 & 47.0 & 141.5 & 2.2 & 5 & 294 & 15.5 \\
\hline 3 & 91.4 & 42.4 & 133.8 & 4.0 & 52 & 298 & 29.9 \\
\hline 4 & 111.0 & 78.0 & 189.0 & 9.3 & 5 & 298 & 49.2 \\
\hline 5 & 104.6 & 78.1 & 182.7 & 6.5 & 53 & 298 & 35.6 \\
\hline 6 & 121.9 & 23.7 & 145.6 & 3.6 & 5 & 290 & 24.7 \\
\hline
\end{tabular}

effect was obtained to be $4.0 \times 10^{-6} \mathrm{~s}^{-1}$, and half-life was $48 \mathrm{~h}$. The detailed result about the ozone wall effect has been reported in $\mathrm{Xu}$ et al. [12]. The reaction rate constant of the $\mathrm{NO}_{2}$ wall effect was $2.41 \times 10^{-6} \mathrm{~s}^{-1}$ and the half-life was $80 \mathrm{~h}$ in our chamber, respectively [14]. The wall loss rate constant of ethanol was measured to be $1.0 \times 10^{-5} \mathrm{~min}^{-1}$, and the half-life was $1155 \mathrm{~h}$ in this study.

Because the heterogeneous formation of HONO by the reaction of $\mathrm{NO}_{2}$ and water is an important $\mathrm{OH}$ radical source in simulation chambers [16-19], the heterogeneous reaction mechanism of $\mathrm{HONO}$ formation was included in our mechanism. Based on $\mathrm{CO}-\mathrm{NO}_{x}$ experiments and ethanol- $\mathrm{NO}_{x}$ experiments, the production rate constant of HONO was determined to be $(1-2) \times 10^{-4} \mathrm{~min}^{-1}$ under our chamber conditions (over the relative humidity range of $5 \%-53 \%$ and temperature range of $293-298 \mathrm{~K}$ ). The ethanol chemical mechanism is involved with 138 reactions and 46 species in MCM v3.1. Hence 46 differential equations are gained.

\section{Results and discussion}

\subsection{Comparison of experimental data and MCM 3.1 simulation}

Table 1 presents the experimental conditions and ozone formation information for 6 chamber experiments. The model (MCM v3.1) simulated profiles of $\mathrm{O}_{3}, \mathrm{NO}_{2}$ and $\mathrm{NO}$ are basically consistent with the observed ones (Figure 1). Note that $y$-axil scale is different for different experiments. Compared with the observed values of $\mathrm{O}_{3}$, the $\mathrm{O}_{3}$ concentrations are relatively well simulated. Particularly for Exp.1, 2, 4 and 6, the difference is less than 5\%, whereas for Exp.3 and Exp.5, the difference is relatively larger, particularly for the late periods of reaction, and the largest deviation can reach about $14 \%$ (Exp.3). Under these experimental conditions, the relatively high deviation may be caused by high relative humidity.

The model-simulated NO profiles can well fit the experimental data, and the difference is generally less than $1.6 \%$ (Figure 1). However, the model generally underestimates the experimental data of $\mathrm{NO}_{2}$, except for Exp.1. The largest underestimate can reach $50 \%$ (Exp.5). This may be due to the measurement error from the equipment of the model 42C. As mentioned by Carter et al. [20], the " $\mathrm{NO}_{2}$ " channel in the model $42 \mathrm{C}$ should include $\mathrm{HNO}_{3}, \mathrm{NO}_{2}, \mathrm{PAN}$, organic nitrates, and other species that may be converted to NO during the measurement by the catalyst. As shown in Figure 2, when the model-simulated PAN and $\mathrm{HNO}_{3}$ are included into $\mathrm{NO}_{2}$, the sum of $\mathrm{NO}_{2}, \mathrm{PAN}$ and $\mathrm{HNO}_{3}$ can well fit the measured $\mathrm{NO}_{2}$ concentrations (right panel). Through these comparisons of plots between chamber experiments and the model simulations, we find that the MCM v3.1 mechanism can well simulate $\mathrm{C}_{2} \mathrm{H}_{5} \mathrm{OH}-\mathrm{NO}_{x}$-air chamber experiments.

\subsection{Radical sources}

Unlike the alkane- $\mathrm{NO}_{x}$ system, the maximum ozone formation in the ethanol- $\mathrm{NO}_{x}$ irradiation system is insensitive to chamber dependent radical sources, such as radical sources from the reaction of $\mathrm{NO}_{2}+\mathrm{H}_{2} \mathrm{O}+\mathrm{M} \rightarrow 0.5 \mathrm{HONO}+0.5 \mathrm{HNO}_{3}$ (R1). The inclusion of the reaction $\mathrm{R} 1$ only accounts for $17 \%$ of maximum ozone formation (Figure 3(c) and (f)). Thus, the beginning step of Ethanol- $\mathrm{NO}_{x}$ irradiation system is sensitive to initial HONO concentrations in the chamber. It can be seen from Figure 3(a), (b), (d) and (e) that without the sufficient initial HONO, the oxidation of ethanol can hardly be induced and the limited $\mathrm{O}_{3}$ is accumulated. When $\mathrm{HONO}_{\text {initial }}$ is set to be $20 \mathrm{ppb}$, the simulated $\mathrm{O}_{3}$ profile is considerably improved (Figure 3(c)). The inclusion of the reaction $\mathrm{R} 1$ can further improve the simulated results (Figure 3(f)). The initial HONO values can be obtained to be 15-20 ppb by fitting experimental data to modeling results, which is in agreement with that by Meagher et al. [21]. The high initial HONO concentration may be due to the large $\mathrm{S} / \mathrm{V}$ ratio of our chamber (about $12.6 \mathrm{~m}^{-1}$ ).

In the absence of initial $\mathrm{HONO}, \mathrm{OH}$ radicals are generated by the $\mathrm{C}_{2} \mathrm{H}_{5} \mathrm{OH}-\mathrm{NO}_{x}$-air irradiation system. It is obvious that R1 is necessary. In the absence of both R1 and $\mathrm{C}_{2} \mathrm{H}_{5} \mathrm{OH}$, the $\mathrm{OH}$ concentration generated from the system is only $0.001 \mathrm{ppt}$ at $t=800 \mathrm{~min}$, as shown in Figure 4(a), which leads to very small $\mathrm{O}_{3}$ in Figure 3(a). In the presence of $\mathrm{R} 1$ without $\mathrm{C}_{2} \mathrm{H}_{5} \mathrm{OH}$, the model generates an $\mathrm{OH}$ concentration of $0.0055 \mathrm{ppt}$ that is still too small to explain the observed $\mathrm{O}_{3}$ concentration. The presence of $\mathrm{C}_{2} \mathrm{H}_{5} \mathrm{OH}$ can 

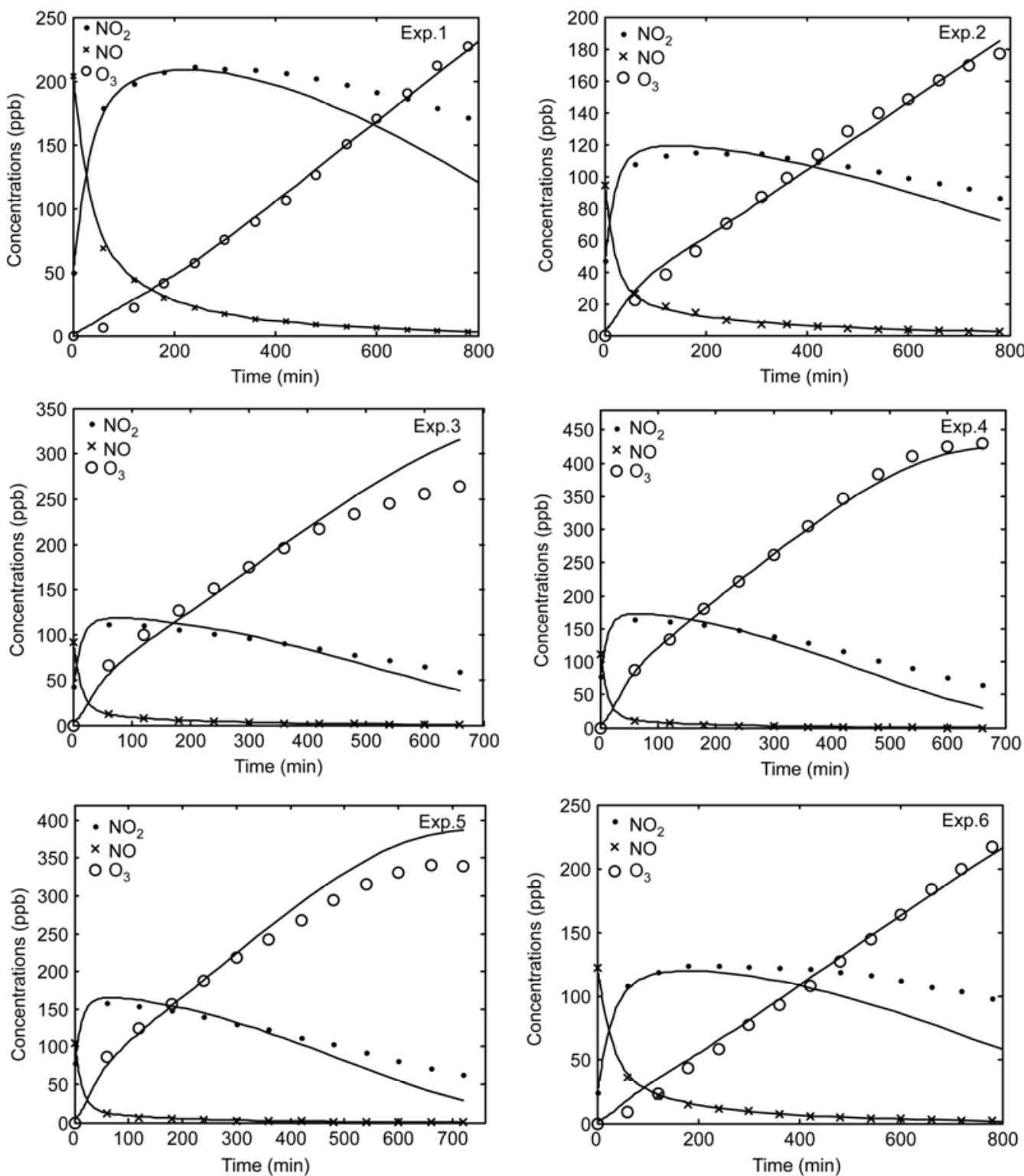

Figure 1 Comparison of the model-simulated and observed concentrations of $\mathrm{NO}, \mathrm{NO}_{2}$ and ozone for 6 smog chamber runs (symbol mark: chamber results, solid line: computer modeling).
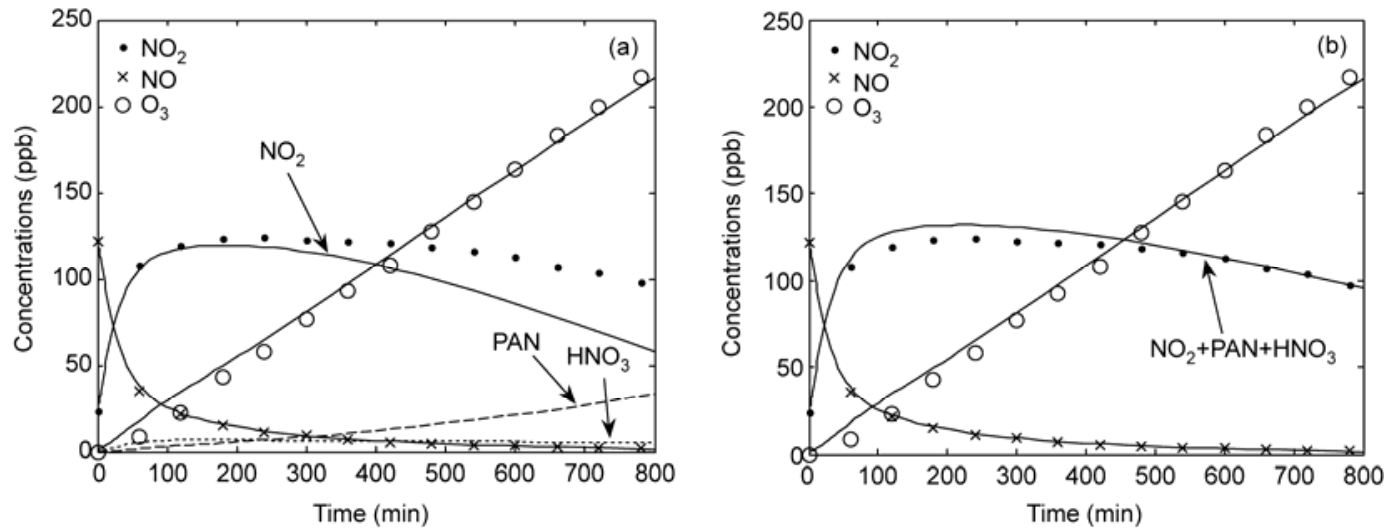

Figure 2 Comparison of measured $\mathrm{NO}_{2}$ with the model-simulated results for Exp.6. 

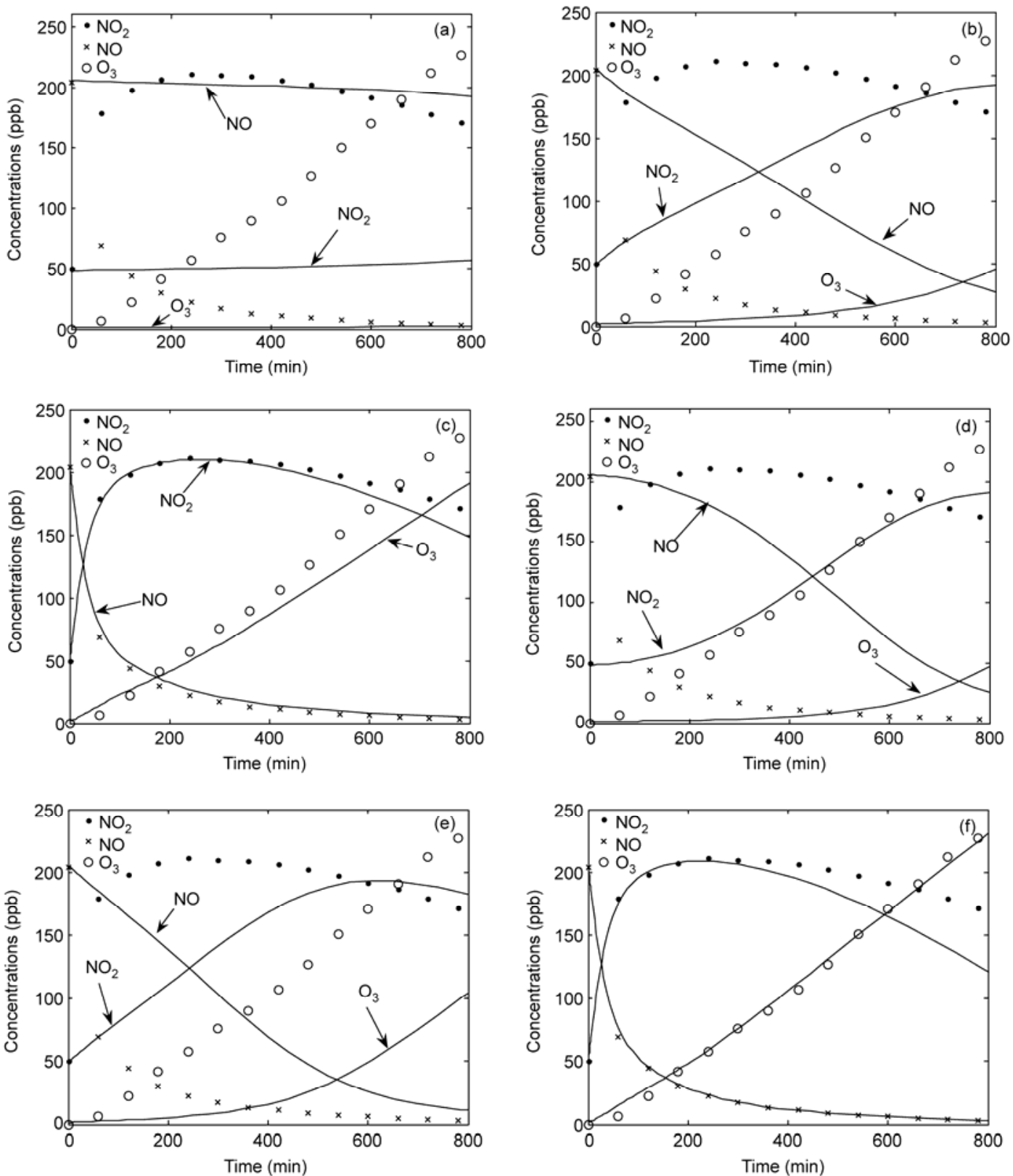

Figure 3 Effects of reaction R1 and initial HONO concentrations on simulated results for Exp.1. (a) $\mathrm{HONO}_{\text {intial }}=0$ without R1; (b) HONO ${ }_{\text {initial }}=2$ ppb without R1; (c) $\mathrm{HONO}_{\text {initial }}=20$ ppb without R1; (d) $\mathrm{HONO}_{\text {initial }}=0$ ppb with R1; (e) $\mathrm{HONO}_{\text {initial }}=2$ ppb with R1; (f) $\mathrm{HONO}_{\text {initial }}=20$ ppb with R1.
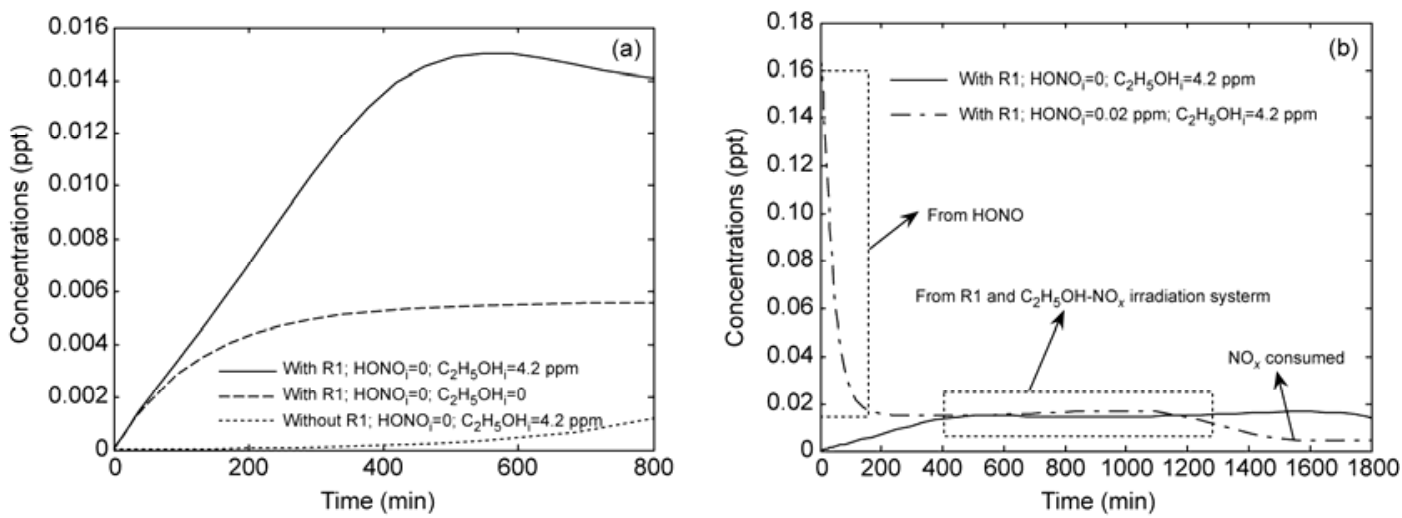

Figure 4 Plots of simulated $\mathrm{OH}$ radical concentrations versus time in Exp.1. 
increase the $\mathrm{OH}$ concentration. Under the condition of 4.2 ppm of $\mathrm{C}_{2} \mathrm{H}_{5} \mathrm{OH}$, the generated $\mathrm{OH}$ concentration is over doubled, which still cannot explain the observed $\mathrm{O}_{3}$. Figure 4(b) further suggests the importance of initial HONO in the $\mathrm{C}_{2} \mathrm{H}_{5} \mathrm{OH}-\mathrm{NO}_{x}$ reaction system. It can be seen that the large $\mathrm{OH}$ concentration from $\mathrm{HONO}$ is necessary to induce the production of $\mathrm{O}_{3}$. As the reaction proceeds, after the reaction time of about $400 \mathrm{~min}$ the maintenance of $\mathrm{OH}$ radical sources will mainly come from the $\mathrm{C}_{2} \mathrm{H}_{5} \mathrm{OH}-\mathrm{NO}_{x}$-air-hv system, which well explains the time evolution of the observed $\mathrm{O}_{3}$ (Figure 3(f)).

From above discussion we can find that the initial HONO have a great effect on ozone accumulation in the beginning step of ethanol- $\mathrm{NO}_{x}$ irradiations. To find out the effects of initial $\mathrm{HONO}$ on the peak $\mathrm{O}_{3}$ concentration, we extend the MCM-simulated time to 1200 minutes. When initial HONO concentrations are reduced from 14 to $1 \mathrm{ppb}$ and other conditions are kept the same as in Exp.4, the results show that the appearance time of peak $\mathrm{O}_{3}$ is delayed about $268 \mathrm{~min}$, while the value of peak $\mathrm{O}_{3}$ is decreased by only $2 \%$ (Figure 5 ). Thus, we can safely conclude that initial HONO concentrations have a great influence on the appearance time of peak $\mathrm{O}_{3}$ and a small effect on the peak $\mathrm{O}_{3}$ value in ethanol- $\mathrm{NO}_{x}$ irradiation.

\subsection{Impacts of relative humidity}

Under low RH conditions, the MCM mechanism can well simulate the observed ozone concentrations in Exp.1, 2, 4 and 6. However, when RH is increased, the observed ozone concentrations are much smaller than the MCM-simulated concentrations. The difference can reach to about $20 \%$ for the maximum ozone concentration, as shown in Exp.3 and Exp.5. We found that the inclusion of $\mathrm{N}_{2} \mathrm{O}_{5}+\mathrm{H}_{2} \mathrm{O} \rightarrow 2 \mathrm{HNO}_{3}$ (R2) in the MCM mechanism can well explain this difference. Under the low RH condition, the reaction $\mathrm{R} 2$ has little effect on ozone formation. With the increase of $\mathrm{RH}$, the effect from R2 becomes important. When RH increases from $5 \%$ to $53 \%$, the difference between the observed and simulated $\mathrm{O}_{3}$ concentration becomes large in the absence of $\mathrm{R} 2$. The effect of $\mathrm{R} 2$ on the $\mathrm{O}_{3}$ concentrations is small even at high $\mathrm{RH}$ for the first $360 \mathrm{~min}$ of the reaction (Figure 6). An increase of RH mainly affects the $\mathrm{O}_{3}$ concentrations for the late period of the experiment. Thus, inclusion of $\mathrm{R} 2$ into MCM considerably improves the simulated results of $\mathrm{O}_{3}$. An increase of $\mathrm{RH}$ increases the rate of $\mathrm{R} 2$, which leads to the decrease of $\mathrm{NO}_{2}$, and finally reduces the formation of ozone.

\subsection{Impacts of $\mathrm{C}_{2} \mathrm{H}_{5} \mathrm{OH} / \mathrm{NO}_{x}$ ratios}

Although $\mathrm{NO}_{x}$ and VOC work together to form ozone, their effects are nonlinear and depend on the ratio of VOC to $\mathrm{NO}_{x}$. The $\mathrm{C}_{2} \mathrm{H}_{5} \mathrm{OH} / \mathrm{NO}_{x}$ ratio determines the priority of either $\mathrm{C}_{2} \mathrm{H}_{5} \mathrm{OH}$ or $\mathrm{NO}_{2}$ reacting with $\mathrm{OH}$ radicals. To test the effects of $\mathrm{C}_{2} \mathrm{H}_{5} \mathrm{OH} / \mathrm{NO}_{x}$ ratio on ozone formation, ozone formation isopleths are plotted in Figure 7 by a series of model simulations, which are based on the MCM v3.1 mechanism and chamber dependent reactions. In order to reflect the chamber experiments, the simulation conditions are close to the experimental conditions, including the irradiation time of $360 \mathrm{~min}$, a relative humidity of $30 \%$, a temperature of $298 \mathrm{~K}$, and the relative light intensity of

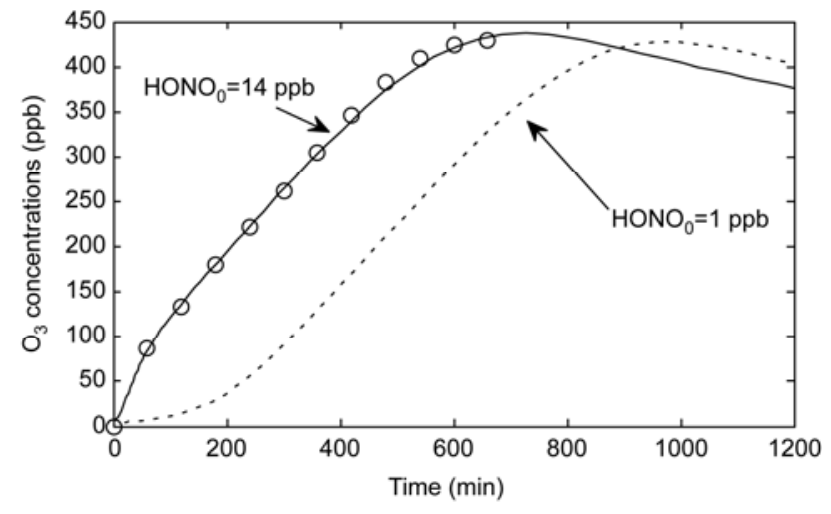

Figure 5 Effects of initial $\mathrm{HONO}$ concentration on peak $\mathrm{O}_{3}$ formation in Exp.4 condition.
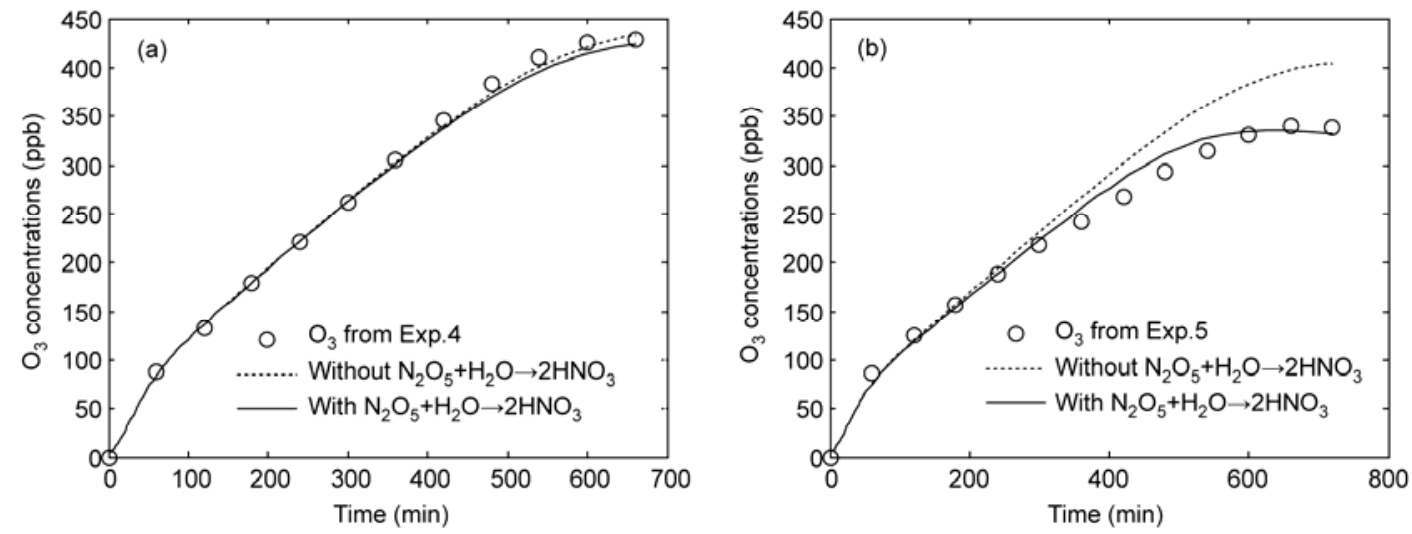

Figure 6 Effects of reaction R2 on model simulations. (a) $\mathrm{RH}=5 \%$; (b) $\mathrm{RH}=53 \%$. 


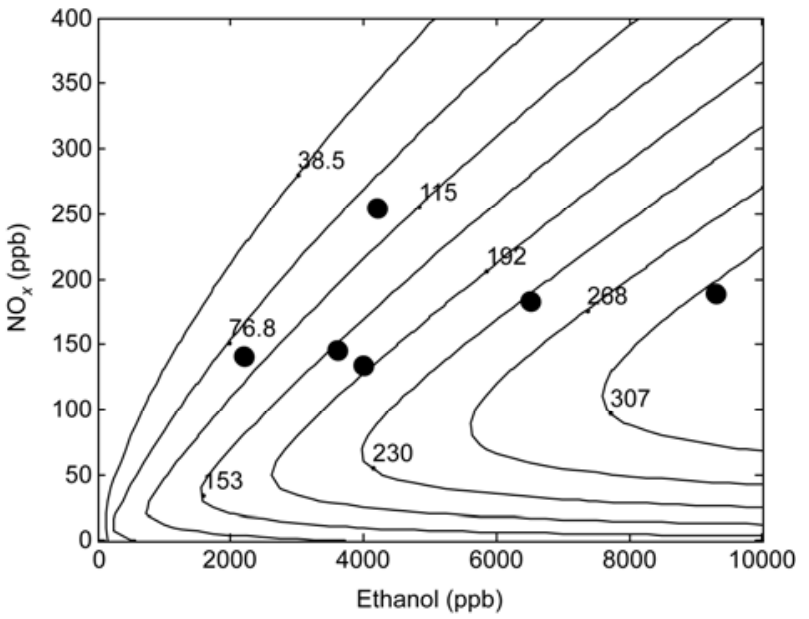

Figure 7 Ozone formation isopleths under experimental conditions.

\section{$0.1572 \mathrm{~min}^{-1}$. The $\mathrm{NO} / \mathrm{NO}_{2}$ ratio is chosen to be 3 .}

It has been noted from chamber experiments that changes in temperature of a few degrees do not affect the results much. The simulation indicates that the influence of $\mathrm{RH}$ on the simulated $\mathrm{O}_{3}$ is small for the reaction time of $6 \mathrm{~h}$. Thus, the ozone formation isopleths can reflect the chamber experiments. The $\mathrm{O}_{3}$ data at $t=360$ min for 6 chamber experiments are shown as solid circles in Figure 7. The deviation of experimental value relative to the isopleth value ranges $-2.2 \%-11 \%$ expect for Exp.6. In Exp.6, the deviation is $-61.6 \%$, which is due to the low initial $\mathrm{NO}_{2}$ concentration of $23.7 \mathrm{ppb}$, which leads to a low initial HONO concentration of $10 \mathrm{ppb}$, whereas in the isopleth condition, the initial HONO is $15 \mathrm{ppb}$. A decrease in temperature of 8 can also reduce the $\mathrm{O}_{3}$ concentration. If the initial HONO concentration is set to be $10 \mathrm{ppb}$ and temperature is set to be $290 \mathrm{~K}$ in the isopleth simulation, $\mathrm{O}_{3}$ from isopleths would be $97.6 \mathrm{ppb}$, so that the deviation would be reduced to $-5.3 \%$. Thus, the model well estimates the chamber measurements. Under low $\mathrm{C}_{2} \mathrm{H}_{5} \mathrm{OH} / \mathrm{NO}_{x}$ ratios (under $\mathrm{C}_{2} \mathrm{H}_{5} \mathrm{OH}$-limited conditions), the increase in $\mathrm{C}_{2} \mathrm{H}_{5} \mathrm{OH}$ concentrations increases the ozone concentration, which is reflected in the results of our experiments.

To further characterize the effects of the $\mathrm{C}_{2} \mathrm{H}_{5} \mathrm{OH} / \mathrm{NO}_{x}$ ratio on the ozone formation, $\mathrm{d}\left(\mathrm{O}_{3}-\mathrm{NO}\right) / \mathrm{d} t$ is used as a definition of reactivity at both the beginning of the experiment when the NO concentration is high, and the late period of the experiment when most of NO has been consumed and a significant amount of $\mathrm{O}_{3}$ has been formed [22]. We chose Exp. 2 and Exp.4 as examples that are shown in Figure 8. At the first 1 hour of the reaction, the $\mathrm{d}\left(\mathrm{O}_{3}-\mathrm{NO}\right) / \mathrm{d} t$ values are determined by the both initial $\mathrm{HONO}$-induced $\mathrm{OH}$ radicals and $\mathrm{C}_{2} \mathrm{H}_{5} \mathrm{OH} / \mathrm{NO}_{2}$ ratio. In the later time, the $\mathrm{d}\left(\mathrm{O}_{3}-\mathrm{NO}\right) / \mathrm{d} t$ values are mainly determined by the $\mathrm{C}_{2} \mathrm{H}_{5} \mathrm{OH} / \mathrm{NO}_{x}$ ratio. The $\mathrm{d}\left(\mathrm{O}_{3}-\mathrm{NO}\right) / \mathrm{d} t$ values for Exp. 4 are 2 times larger than those for Exp.2. This can be well explained by the difference in the $\mathrm{C}_{2} \mathrm{H}_{5} \mathrm{OH} / \mathrm{NO}_{x}$ ratio. In fact, the $\mathrm{C}_{2} \mathrm{H}_{5} \mathrm{OH} / \mathrm{NO}_{x}$

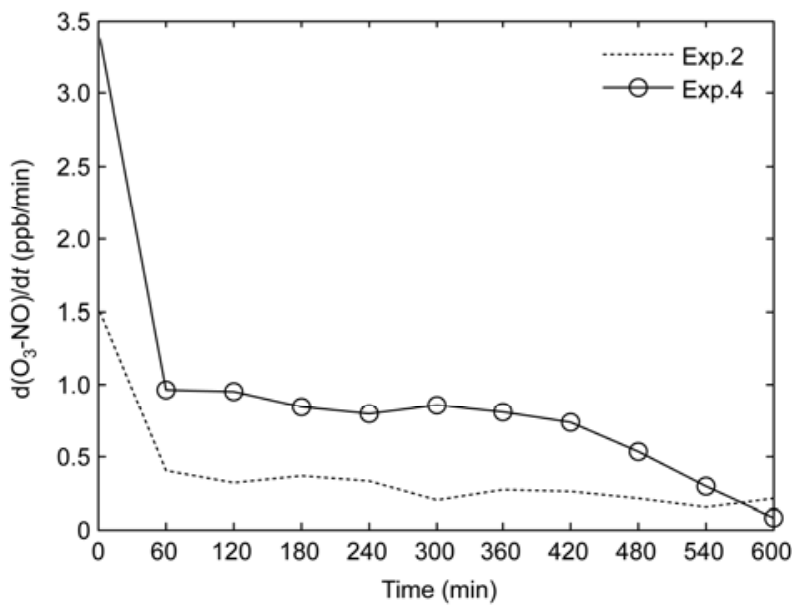

Figure $8 \mathrm{~d}\left(\mathrm{O}_{3}-\mathrm{NO}\right) / \mathrm{d} t$ versus irradiation time.

ratio in Exp.4 is 3 times larger than that in Exp.2. When the $\mathrm{C}_{2} \mathrm{H}_{5} \mathrm{OH} / \mathrm{NO}_{2}$ ratio is high, more $\mathrm{C}_{2} \mathrm{H}_{5} \mathrm{OH}$ can be oxidized by the $\mathrm{OH}$ radicals, so that the conversion of $\mathrm{NO}$ to $\mathrm{NO}_{2}$ induced by added ethanol is increased and the $\mathrm{d}\left(\mathrm{O}_{3}-\mathrm{NO}\right) / \mathrm{d} t$ value is high. $\mathrm{d}\left(\mathrm{O}_{3}-\mathrm{NO}\right) / \mathrm{d} t$ removes the effects of $\mathrm{NO} / \mathrm{NO}_{2}$ ratios from $\mathrm{dO}_{3} / \mathrm{d} t$. In our experiments the value of $\mathrm{d}\left(\mathrm{O}_{3}\right.$ $\mathrm{NO}) / \mathrm{d} t$ ranges from 1.0 to $0.1 \mathrm{ppb} / \mathrm{min}$ after $60 \mathrm{~min}$ of reaction, which can be used to explain the ethanol reactivity.

The concentration of organo-peroxide radicals $\left(\mathrm{RO}_{2}\right)$ and $\mathrm{HO}_{2}$ can explain why the high $\mathrm{C}_{2} \mathrm{H}_{5} \mathrm{OH} / \mathrm{NO}_{x}$ ratios can increase the $\mathrm{d}\left(\mathrm{O}_{3}-\mathrm{NO}\right) / \mathrm{d} t$ values. When the reaction rate of $\mathrm{C}_{2} \mathrm{H}_{5} \mathrm{OH}$ with $\mathrm{OH}$ is larger than that of $\mathrm{NO}_{2}$ with $\mathrm{OH}$, the $\mathrm{OH}$ will react with $\mathrm{C}_{2} \mathrm{H}_{5} \mathrm{OH}$ to produce more peroxide radicals. The conversion of $\mathrm{NO}$ to $\mathrm{NO}_{2}$ is induced by $\mathrm{RO}_{2}$ and $\mathrm{HO}_{2}$ radicals. Thus the production ability of $\mathrm{RO}_{2}+\mathrm{HO}_{2}$ from the ethanol oxidation can provide a measure for the ozone formation reactivity of ethanol mechanism. The $\mathrm{RO}_{2}+\mathrm{HO}_{2}$ concentrations computed from the model simulations generally increase with the irradiation time (Figure 9). A small peak in the $\mathrm{RO}_{2}+\mathrm{HO}_{2}$ concentration profiles may be caused

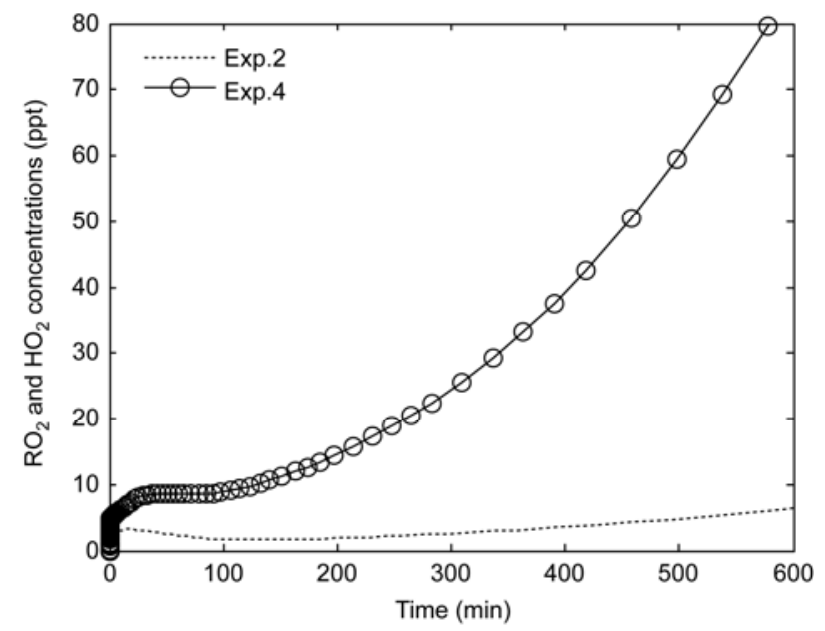

Figure $9 \mathrm{RO}_{2}$ and $\mathrm{HO}_{2}$ radical concentrations versus irradiation time. 
by high $\mathrm{OH}$ concentrations at the beginning of experiments. After a few minutes from the beginning of the reaction, the $\mathrm{RO}_{2}+\mathrm{HO}_{2}$ concentrations in Exp.4 increases much faster than those in Exp.2. This difference in the production ability of $\mathrm{RO}_{2}+\mathrm{HO}_{2}$ demonstrates the influences of the $\mathrm{C}_{2} \mathrm{H}_{5} \mathrm{OH} /$ $\mathrm{NO}_{x}$ ratio on the ozone production rate (in the form of $\mathrm{d}\left(\mathrm{O}_{3^{-}}\right.$ $\mathrm{NO}) / \mathrm{d} t$ ).

\subsection{Ozone formation potential of ethanol}

To study the ozone formation potential of ethanol near real atmospheric conditions, three scenarios are introduced in this study, which include the levels of $\mathrm{NO}_{x}$ and ethanol in normal cities, cities using ethanol gas and remote areas. The typical initial conditions of $\mathrm{NO}_{x}$, ethanol and $\mathrm{HONO}$ are listed in Table 2. According to the study of Cater [20], the ozone concentration at the end of the 6th hour is used to represent the actual ozone formation ability of ethanol under typical sun light irradiations and the maximum ozone concentration (or peak ozone concentration) is used to represent the ozone formation potential.

The 6th hour $\mathrm{O}_{3}$ concentrations are computed with MCM v3.1, which is called the 6th hour ozone formation isopleths in Figure 10. The conditions used in Figure 10(a) are taken from the scenarios of normal cities and cities using ethanol gas. The marked areas with dashed lines in Figure 10(a) are considered to be present in the urban atmosphere. Figure 10(a) indicates that ethanol can generate about 2.3-3.5 ppb ozone in normal cities, and 3.5-146 ppb ozone in cities where ethanol gas are widely used. It shows that both areas are in ethanol limited side in city conditions, so ozone concentrations will increase with the decrease of $\mathrm{NO}_{x}$ concentrations under the condition of $0.7-414 \mathrm{ppb}$ ethanol. The condition in Figure 10(b) is taken from the scenario of re- mote area. Results shows that the 6th hour ozone concentration is about $0.2-3.2 \mathrm{ppb}$, which is quite small.

Howard et al. [11] studied the $\mathrm{O}_{3}$ formation of ethanol by chamber experiments and model simulations (a modified form of the Caltech Atmospheric Chemistry Mechanism). Their results showed that the concentration of formation of $\mathrm{O}_{3}$ from the irradiation of ethanol was $<20 \mathrm{ppb}$ under typical conditions (ethanol $\sim 200 \mathrm{ppb}$ and $\mathrm{NO}_{x} \sim 50 \mathrm{ppb}$ ). Using their conditions, it is estimated that the $\mathrm{O}_{3}$ concentration at the end of the 6th hour in our study is about $50 \mathrm{ppb}$. If the irradiation time of $3 \mathrm{~h}$ used in Howard et al.'s work is used for our computation, it can be obtained that the $\mathrm{O}_{3}$ concentration at the end of the $3 \mathrm{rd}$ hour is $30 \mathrm{ppb}$ in our work. The difference in $\mathrm{O}_{3}$ concentrations of $10 \mathrm{ppb}$ is probably due to the different light intensities or different mechanisms used in model simulations.

The ozone formation potential can be characterized by maximum ozone concentrations. The simulated results from the scenarios of normal city and cities using ethanol gas are shown in Figure 11(a), in which the same conditions as in Figure 10(a) are used. The maximum ozone formation isopleths are independent on the $\mathrm{NO} / \mathrm{NO}_{2}$ ratios. The marked areas indicate that the ozone formation potential is $4.0-5.8$ ppb in normal cities, and 5.8-305 ppb in cities using ethanol gas. The ozone formation potential of ethanol in remote areas is $0.2-3.8 \mathrm{ppb}$, as shown in Figure 11(b).

To better understand the importance of ethanol in the formation of ozone, isopentane and ethylene are chosen to be the representative VOC species for the comparison because a series of chamber experiments with model simulations have been conducted in our laboratory. The maximum ozone formation isopleths of these species are plotted using the same conditions as those in the ethanol simulation, which is shown in Figure 12. It can be seen from the marked

Table 2 Initial conditions and simulated results for different scenarios

\begin{tabular}{|c|c|c|c|c|c|c|c|}
\hline Scenarios & $\mathrm{NO}_{x}(\mathrm{ppb})$ & Ethanol (ppb) & HONO (ppb) & Light intensity $\left(\mathrm{min}^{-1}\right)$ & $\mathrm{RH}(\%)$ & $\mathrm{O}_{36 \mathrm{~h}}(\mathrm{ppb})$ & $\mathrm{O}_{3 \max }(\mathrm{ppb})$ \\
\hline Normal cities & $50-200$ & $0.7-12$ & 4 & 0.5669 & 50 & $2.3-3.5$ & $4.0-5.8$ \\
\hline Cities using ethanol gas & $50-200$ & $12.1-414$ & 4 & 0.5669 & 50 & $3.5-146$ & $5.8-305$ \\
\hline Remote areas & $0.1-15$ & $0.04-1.2$ & 0.001 & 0.5669 & 50 & $0.2-3.2$ & $0.2-3.8$ \\
\hline
\end{tabular}
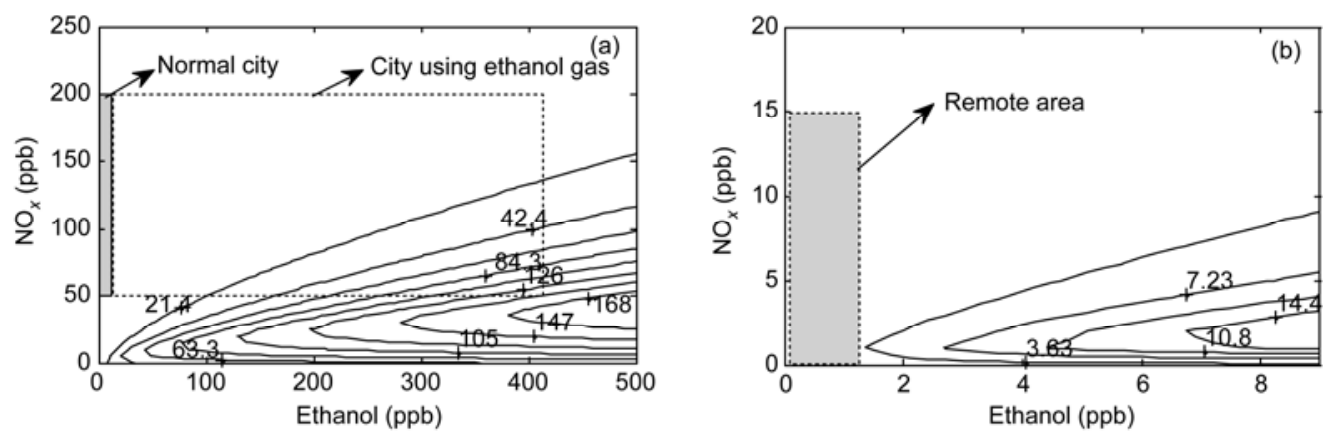

Figure 10 Model predictions of the $6 \mathrm{~h}$ ozone formation isopleths under city (a) and remote area (b) conditions. 

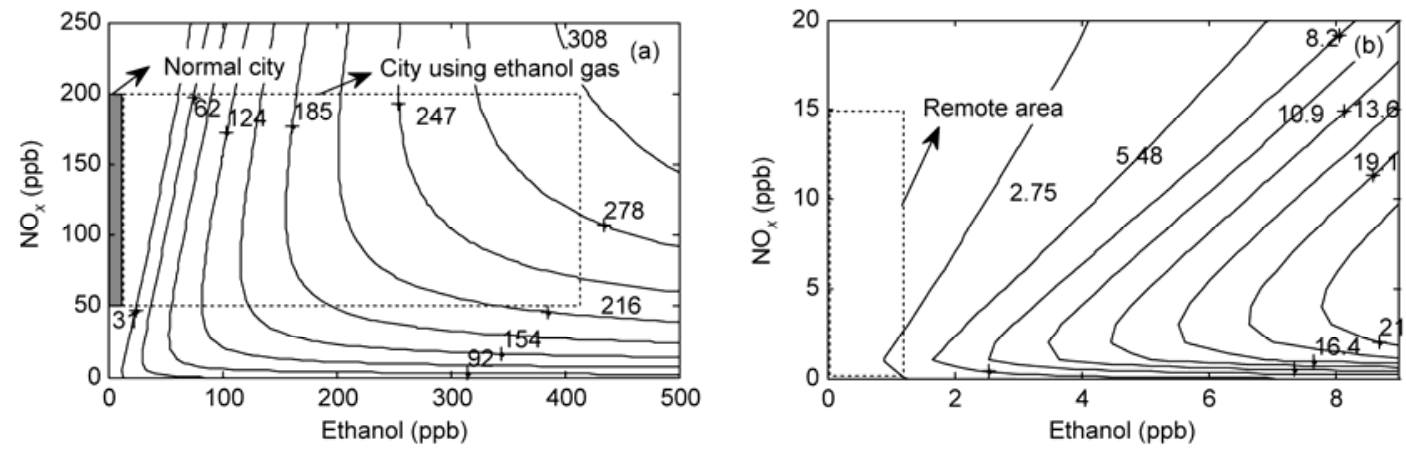

Figure 11 Maximum ozone formation isopleths under city (a) and remote area (b) conditions.
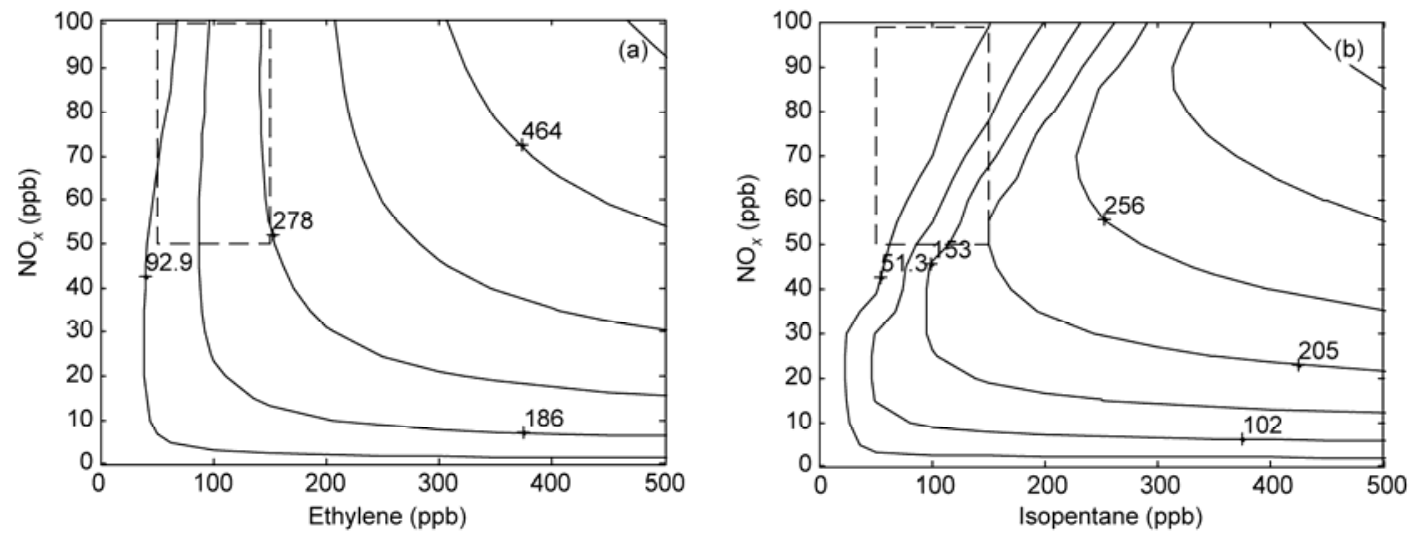

Figure 12 Maximum ozone formation isopleths of ethylene (a) and isopentane (b).

area with dashed lines that the ozone formation potential from ethylene is much higher than that from isopentane.

Table 3 shows the ozone formation potentials from the isopleths and MIR. Using the same range of $\mathrm{NO}_{x}$ and VOC concentrations, it can be known that the ozone formation potential of ethanol is smaller, compared to that of ethylene or isopentane. However, if ethanol-oil is widely used in the future, the contribution of ethanol to ozone formation cannot be ignored. Using the MIR and VOC values, we can also estimate the ozone formation potential. The low bounds of maximum ozone formation for these species from both methods are roughly in agreement. The ratio of the ethylene MIR value to the ethanol one is close to their ratio of the maximum ozone formation from the isopleths for the low bound. This is because the condition for the low bound obtained from the isopleths is close to the MIR condition under which VOC is limited.

\section{Conclusions}

The irradiation of $\mathrm{C}_{2} \mathrm{H}_{5} \mathrm{OH}-\mathrm{NO}_{x}$ system has been studied using 6 chamber experiments and model simulations for the ozone formation reactivity of ethanol. The MCM submechanism of ethanol with chamber-dependent auxiliary reactions has been used in the simulations. The simulated results of $\mathrm{O}_{3}$ and $\mathrm{NO}$ from the MCM mechanism are in good agreement with the experimental data. The simulated results of $\mathrm{NO}_{2}$ suggest the inclusion of $\mathrm{HNO}_{3}$ and PAN into the " $\mathrm{NO}_{2}$ " channel in the instrument model 42C. An initial HONO concentration of about $20 \mathrm{ppb}$ is necessary for the simulation of experimental data from our chamber.

The heterogeneous reaction of $\mathrm{NO}_{2}$ and water has been confirmed to be an important source for $\mathrm{OH}$ radicals in chamber simulations. The reaction rate constant for $\left(\mathrm{NO}_{2}\right.$ $\rightarrow$ HONO) was determined to be $(1.0 \pm 0.2) \times 10^{-4} \mathrm{~min}^{-1}$. It

Table 3 MIR and Maximum ozone formation of the selected species

\begin{tabular}{lcccc}
\hline Species & $\mathrm{NO}_{x}\left(\mathrm{NO} / \mathrm{NO}_{2}=3\right)(\mathrm{ppb})$ & VOC $(\mathrm{ppb})$ & MIR $_{(\text {Carter })}$ & Maximum ozone formation (ppb) \\
\hline $\mathrm{C}_{2} \mathrm{H}_{5} \mathrm{OH}$ & & & 0.43 \\
$i-\mathrm{C}_{5} \mathrm{H}_{12}$ & $50-100$ & $50-150$ & 0.44 & $5.5-169$ \\
$\mathrm{C}_{2} \mathrm{H}_{4}$ & & & 2.40 & $38-204$ \\
\hline
\end{tabular}


has been found that $\mathrm{C}_{2} \mathrm{H}_{5} \mathrm{OH}-\mathrm{NO}_{x}$ irradiations are less sensitive to humidity than alkanes under our experimental conditions. An increase in $\mathrm{RH}$ mainly affects the $\mathrm{O}_{3}$ concentrations for the late period of the reaction. The reaction $\mathrm{N}_{2} \mathrm{O}_{5}+$ $\mathrm{H}_{2} \mathrm{O} \rightarrow 2 \mathrm{HNO}_{3}$ is important for the improvement of simulated $\mathrm{O}_{3}$ in the late period. The $\mathrm{d}\left(\mathrm{O}_{3}-\mathrm{NO}\right) / \mathrm{d} t$ values are used to explain the $\mathrm{C}_{2} \mathrm{H}_{5} \mathrm{OH} / \mathrm{NO}_{x}$ ratio on the $\mathrm{O}_{3}$ formation, which generally ranges from 1.0 to $0.1 \mathrm{ppb} / \mathrm{min}$ after $60 \mathrm{~min}$ of reaction. A large $\mathrm{C}_{2} \mathrm{H}_{5} \mathrm{OH} / \mathrm{NO}_{x}$ ratio generates large a $\mathrm{d}\left(\mathrm{O}_{3}\right.$ $\mathrm{NO}$ )/dt value, which is further explained with the production of organo-peroxide radicals and $\mathrm{HO}_{2}$ radical concentrations.

Both actual and maximum ozone formation under three different scenarios are simulated with MCM. Results show that ethanol have a very small ozone formation both in normal cities and remote areas, however, ethanol may be an important species for $\mathrm{O}_{3}$ formation if the ethanol-fuels are widely used in the future.

This work was supported by the Knowledge Innovation Program of the Chinese Academy of Sciences (KZCX2-YW-Q02-03) and the National Natural Science Foundation of China (41105086).

1 Carter W P L, Atkinson R. An experimental study of incremental hydrocarbon reactivity. Environ Sci Technol, 1987, 21: 670-679

2 Xin J Y, Wang Y S, Tang G Q, et al. Variability and reduction of atmospheric pollutants in Beijing and its surrounding area during the Beijing 2008 Olympic Games. Chin Sci Bull, 2010, 55: 1937-1944

3 Carter W P L. Development of ozone reactivity scales for volatile organic compounds. J Air Waste Manag Assoc, 1994, 44: 881-899

4 Kelly N A, Chang T Y. An experimental investigation of incremental reactivities of volatile organic compounds. Atmos Environ, 1999, 33: 2101-2110

5 Wu S, Hao J M, Lu Z F, et al. Effect of ammonium sulfate aerosol on the photochemical reaction of toluene $/ \mathrm{NO}_{x} /$ air mixture. Chin J Environ Sci, 2007, 28: 1183-1187

6 Wang K, Du L, Ge M F. Environmental chamber study of the photochemical reaction of ethyl methyl sulfide and $\mathrm{NO}_{x}$. J Environ Sci, 2009, 21: 137-141
7 Monod A, Bonnefoy N, Kaluzny P, et al. Methods for sampling and analysis of tropospheric ethanol in gaseous and aqueous phases. Chemosphere, 2003, 52: 1307-1319

8 Kelly J T, Callahan P J, Pleil J, et al. Method development and field measurements for polar volatile organic compounds in ambient air. Environ Sci Technol, 1993, 27: 1146-1153

9 Pereira P A D, Santos L M B, Sousa E T, et al. Alcohol- and gasohol-fuels: A comparative chamber study of photochemical ozone formation. J Brazil Chem Soc 2004, 15: 646-651

10 Jacobson M Z. Effects of ethanol (e85) versus gasoline vehicles on cancer and mortality in the United States. Environ Sci Technol, 2007, 41: 4150-4157

11 Howard C J, Yang W L, Green P G, et al. Direct measurements of the ozone formation potential from dairy cattle emissions using a transportable smog chamber. Atmos Environ, 2008, 42: 5267-5277

$12 \mathrm{Xu} \mathrm{Y} \mathrm{F,} \mathrm{Jia} \mathrm{L,} \mathrm{Ge} \mathrm{M} \mathrm{F,} \mathrm{et} \mathrm{al.} \mathrm{A} \mathrm{kinetic} \mathrm{study} \mathrm{of} \mathrm{the} \mathrm{reaction} \mathrm{of} \mathrm{ozone}$ with ethylene in a smog chamber under atmospheric conditions. Chin Sci Bull, 2006, 51: 2839-2843

13 Jia L, Xu Y F, Ge M F, et al. Kinetic study of the gas-phase ozonolysis of propylene. Acta Phys-Chim Sin, 2006, 22: 1260-1265

14 Du L, Xu Y F, Ge M F, et al. Smog chamber simulation of atmospheric photochemical reactions of acetylene and $\mathrm{NO}_{x}$ (in Chinese). Chin J Environ Sci, 2007, 28: 482-488

15 Jia L, Xu Y F, Ge M F, et al. Smog chamber studies of ozone formation potentials for isopentane. Chin Sci Bull, 2009, 54: 4624-4632

16 Carter W P L, Atkinson R, Winer A M, et al. Evidence for chamber-dependent radical source: Impact on kinetic computer models for air pollution. Int J Chem Kinet, 1981, 13: 735-740

17 Kleffmann J, Becker K H, Wieses P. Heterogeneous $\mathrm{NO}_{2}$ conversion processes on acid surfaces possible atmospheric implications. Atmos Environ, 1998, 32: 2721-2729

18 Aumont B, Chervier F, Laval S. Contribution of HONO sources to the $\mathrm{NO}_{x} / \mathrm{HO}_{x} / \mathrm{O}_{3}$ chemistry in the polluted boundary layer. Atmos Environ, 2003, 37: 487-498

19 Rohrer F, Bohn B, Brauers T, et al. Characterisation of the photolytic HONO-source in the atmosphere simulation chamber SAPHIR. Atmos Chem Phys, 2005, 5: 2189-2201

20 Carter W P L, Cocker III D R, Fitz D, et al. A new environmental chamber for evaluation of gas-phase chemical mechanisms and secondary aerosol formation. Atmos Environ, 2005, 39: 7768-7788

21 Meagher J F, Olszyna K J, Simonaitis R. Smog chamber study of $\mathrm{H}_{2} \mathrm{O}_{2}$ formation in ethane- $\mathrm{NO}_{x}$ and propene- $\mathrm{NO}_{x}$ mixtures. Int $\mathrm{J}$ Chem Kinet, 1990, 22: 719-740

22 Bloss C, Wagner V, Bonzanini A, et al. Evaluation of detailed aromatic mechanisms (MCMv3 and MCMv3.1) against environmental chamber data. Atmos Chem Phys, 2005, 5: 623-639

Open Access This article is distributed under the terms of the Creative Commons Attribution License which permits any use, distribution, and reproduction in any medium, provided the original author(s) and source are credited. 